\title{
Strategi Koping, Dukungan Petugas, dan Kesejahteraan Psikologis Anak Berkonflik dengan Hukum
}

\author{
Sri Maslihah \\ Universitas Pendidikan Indonesia, Jl. Setiabudhi No. 229, Kota Bandung \\ e-mail: maslihah_psi@upi.edu
}

\begin{abstract}
This study aims to obtain empirical data related to the influence of coping strategies and support officers in the formation of psychological well-being of conflicted-children with law. The Conflicted children with law is the children of the perpetrators of criminal acts and must undergo guidance in Protective Institution for children (LPKA). This research is a quantitative descriptive approach. Subject of this study amounted to 43 conflicting children with the law who undergo guidance in LPKA Tangerang selected through purposive sampling technique. The measurement tool used in this study consists of the questionnaire of integrative well-being (Maslihah, 2017), coping strategy (Moos, 2002), and officer support (Maslihah, 2017). The result of this study shows that when faced with pressing situation, psychological well-being can be influenced by coping strategy (internal factor) and officer support (external factor). Support officers can serve as a moderator variable in the relationship of coping strategies and psychological well-being of conflicted children with law. Future research can analyze based on cases of criminal acts committed by children accompanied by qualitative data.
\end{abstract}

Keywords: conflicted-children with law, coping strategies, officer support, psychological wellbeing

\begin{abstract}
Abstrak
Penelitian ini bertujuan untuk mendapatkan data empiris terkait pengaruh strategi koping dan dukungan petugas terhadap kesejahteraan psikologis anak berkonflik dengan hukum. Anak berkonflik dengan hukum yang dimaksud adalah anak-anak pelaku tindak pidana yang harus menjalani pembinaan di Lembaga Pembinaan Khusus Anak (LPKA) . Penelitian ini merupakan penelitian deskriptif kuantitatif. Subyek penelitian ini berjumlah 43 anak berkonflik dengan hukum yang menjalani pembinaan di LPKA Tangerang yang dipilih melalui teknik purposive sampling. Alat ukur yang digunakan terdiri dari angket kesejahteraan psikologis integratif (Maslihah, 2017), strategi koping (Moos, 2002), dan dukungan petugas (Maslihah, 2017). Hasil penelitian menunjukkan ketika dihadapkan pada situasi menekan, kesejahteraan psikologis anak berkonflik dengan hukum dapat dipengaruhi oleh faktor internal, yaitu strategi koping dan faktor eksternal, yaitu dukungan petugas. Dukungan petugas dapat berperan sebagai moderator dalam hubungan strategi koping dan kesejahteraan psikologis anak berkonflik dengan hukum. Penelitian selanjutnya disarankan melakukan kajian berdasarkan kasus tindak pidana atau melalui pendekatan kualitatif.
\end{abstract}

Kata Kunci: anak berkonflik dengan hukum, strategi koping, dukungan petugas, kesejahteraan psikologis

\section{Pendahuluan}

Fenomena saat ini menunjukkan bahwa jumlah remaja yang terlibat dalam tindak kriminalitas atau pelanggaran hukum menunjukkan peningkatan dari tahun ke tahun. Data pada Badan Pusat Statistik (BPS) tahun 2013 angka kenakalan remaja di Indonesia mencapai 6.325 kasus, tahun 2014 jumlahnya mencapai 7.007 kasus, dan tahun 2015 mencapai 7.762 kasus. Sementara data pada Komisi Perlindungan Anak Indonesia (KPAI) dari tahun 2011 hingga 2016 terdapat 7.132 kasus anak dan remaja yang berhadapan dengan hukum.

Data pada Direktorat Reserse Kriminal Umum (Ditreskrimum) Polda Jawa Barat sampai akhir tahun 2016 dari 1.860 orang anak berhadapan dengan hukum di Jawa Barat, terdapat 930 orang anak yang meru- 
pakan anak pelaku tindak kriminal atau anak berkonflik dengan hukum. Kondisi ini tentu sangat memprihatinkan mengingat di usia mereka seharusnya mereka mampu meraih prestasi untuk bekal dan persiapan menuju kehidupan di masa dewasa.

Maslihah, Siregar, Koesma, dan Agustiani (2015) mengungkapkan bahwa perubahan yang pasti dihadapi anak berkonflik dengan hukum yang menjalani pembinaan di Lembaga Pembinaan Khusus Anak (selanjutnya disingkat LPKA) adalah mereka harus berpisah dari keluarga dan teman-teman. Padahal keduanya merupakan bagian yang tidak terpisahkan dalam proses perkembangan anak. Di saat anakanak lain mengembangkan diri menuju kemandirian pribadi sebagai bekal masa dewasa, anak-anak di dalam LPKA menjalani kehidupan yang berbeda karena kehilangan kebebasan untuk berinteraksi secara fisik dengan masyarakat luas dan harus menjalani kegiatan rutin dalam lingkungan yang terbatas sehingga sangat memungkinkan untuk memunculkan rasa jenuh dan bosan. Namun demikian, sebagaimana anak-anak lain di luar LPKA mereka tetap memiliki hak untuk menjalani masa remaja dengan optimal sebagai bekal menuju masa dewasa.

Beberapa ahli telah melakukan kajian terkait kondisi psikologis anak di lingkungan lembaga pemasyarakatan (Maitland \& Sluder, 1996; Mohino. \& Kirchner, Forns, 2004; Whitehead \& Steptoe, 2007). Anak-anak yang tinggal di lembaga pemasyarakatan menunjukkan ketidakmampuan untuk mengatasi stres akibat pemenjaraan yang dialami dan mengalami kecemasan yang lebih tinggi sehubungan perpisahan dengan anggota keluarga dan lingkungan sosial (MacKenzie, 1987; McShane \& Williams, dalam Cesaroni \& Badali, 2010). Namun demikian penelitian terdahulu menunjukkan adaptasi anak dalam lingkungan lembaga pemasyarakatan berhubungan dengan interaksi dengan teman sebaya, interaksi dengan staf penjara dan kegiatan sehari-hari seperti kegiatan sekolah ataupun rekreasi (bermain). Dukungan dari teman sebaya dan staf penjara berdampak positif bagi anak dalam memunculkan perasaan aman dan meningkatkan kesejahteraan anak di lembaga pemasyarakatan (Solichatun, 2012; Laan \& Eichelsheim, 2013).

Penelitian-penelitian sebelumnya menunjukkan bahwa kemampuan anak dalam melakukan koping, adanya dukungan sosial baik yang bersumber dari keluarga maupun teman memberikan kontribusi terhadap munculnya perkembangan positif pada diri anak termasuk kesehatan mental meskipun anak dihadapkan pada berbagai masalah dan situasi menekan di lingkungan lembaga pemasyarakatan (Mohino dkk., 2004; Faizza, 2009; Handayani, 2012; Solichatun, 2012; Puspita, 2013). Terkait dengan anakanak di lembaga pemasyarakatan anak atau LPKA, Helsen, Volleberg, dan Meeus (2000) menyatakan perpisahan yang terjadi sehubungan proses pembinaan di lembaga pemasyarakatan berkaitan dengan wellbeing anak. Ochse dan Plug (1986) menyatakan bahwa perkembangan psikososial pada anak berkaitan dengan kesejahteraan psikologis.

Weiss dan Lopez (1999) dan Bradshaw, Hoelscher, dan Richardson (2006) mengungkapkan pentingnya mengusahakan perkembangan yang positif pada anak yang bermasalah seperti anak-anak yang berkonflik dengan hukum. Demikian pula Barnet, Perry, Azzi, Shetgiri, Ryan, Dudovitz, Zima, dan Chung (2015) menunjukkan bahwa anak-anak yang menjalani pembinaan di lembaga sejenis LPKA membutuhkan program intervensi yang mampu mendo-rong munculnya prestasi bukan sebaliknya. Berdasarkan hal tersebut peneliti ber-pendapat mengkaji kesejahteraan subyektif dalam konteks anak-anak di LPKA akan membantu upaya menggali potensi-potensi positif yang bisa dikembangkan selama anak menjalani pembinaan di lembaga pemasyarakatan anak. 
Beranjak dari studi pendahuluan yang dilakukan terkait makna well-being bagi anak berkonflik dengan hukum atau anak didik LPKA, Maslihah dkk. (2015). menemukan bahwa kesejahteraan psikologis yang dimaknai anak didik LPKA, antara lain: komponen kognitif, kepuasan hidup dan adanya penilaian subyektif anak terhadap dirinya yang akan menggambarkan harga diri anak. Sedangkan penilaian afektif berupa adanya emosi positif serta adanya komponen sikap, khususnya sikap positif terhadap hidup (Maslihah dkk., 2015)

Konsep well-being yang akan digali dalam penelitian ini adalah kesejahteraan psikologi integratif (Maslihah, 2017) yang merupakan konsep kesejahteraan psikologis anak berkonflik dengan hukum atau anak didik LPKA. Konsep well-being ini dikembangkan dari konsep subyektif well-being Diener (1984). Hasil studi yang dilakukan diperoleh temuan adanya dimensi-dimensi baru sebagai tambahan dari dimensi subyektif well-being Diener dan hasil penelitian yang dilakukan menunjukkan terdapat empat dimensi well-being anak didik LPKA, yaitu kepuasan hidup, sikap positif terhadap hidup, adanya emosi positif yang sekaligus mereduksi emosi negatif, dan rasa keberhargaan diri (Maslihah dkk., 2015). Keempat dimensi ini dapat dilihat pada area atau domain-domain kehidupan anak di lingkungan LPKA, yang mencakup area yang berkaitan dengan lingkungan sekolah yang disebut peneliti sebagai domain akademik, area berkaitan dengan kepemimpinan atau organisasi diantara anak didik LPKA, yang disebut peneliti sebagai domain organisasi. Domain kegiatan meliputi area pergaulan mencakup relasi anak dengan sesama anak didik LPKA, relasi dengan petugas serta keterlibatan anak dengan kegiatan-kegiatan yang ada di LPKA di luar kegiatan sekolah termasuk kegiatan olah raga (Maslihah, 2017).

Kesejahteraan psikologis anak berkonflik dengan hukum tidak bisa dilepaskan dari karakteristik dan kebutuhan anak kelompok usia 14-18 tahun secara umum, hanya terdapat perbedaan pada konteks kehidupan. Bagaimanapun adanya perasaan sejahtera dalam diri akan membuat individu untuk mampu bertahan serta memaknai kesulitan yang dialami sebagai pengalaman hidupnya. Konsep kesejahteraan psikologis banyak diteliti dari berbagai sudut pandang dengan bermacam-macam variabel yang mewakili konteks yang berbeda. Diener (2009) mengungkapkan bahwa tidak ada faktor tunggal yang menjadi penentu kesejahteraan psikologis. Penelitian ini akan mengkaji kemampuan internal anak dalam mengatasi situasi menekan yang dikenal sebagai strategi koping. Meskipun situasi yang dihadapi anak berkonflik dengan hukum saat ini mengalami perubahan dari sistem pemasyarakatan yang identik dengan sistem pemenjaraan menjadi sistem lembaga pembinaan, namun pada dasarnya kondisi yang tidak berbeda antara dua sistem tersebut dalam arti berpotensi menjadi stresor. Kondisi yang bisa menimbulkan tekanan tersebut diantaranya; keterpisahan dengan lingkungan asal tetap terjadi yang menjadi sumber kehilangan anak, pembatasan-pembatasan baik berkaitan dengan interaksi dengan dunia luar maupun pembatasan dalam beraktivitas di dalam lingkungan LPKA dan waktu untuk beraktivitas (Maslihah dkk., 2016).

Konsep strategi koping yang digunakan dalam penelitian ini mengacu pada delapan jenis strategi koping yang dikembangkan Moos (2002). Moos (dalam Mohino, Kirchner, Forns, 2004) secara lebih rinci menggambarkan dalam inventori respon kopingnya, beragam bentuk strategi dengan metode kognitif maupun perilaku baik yang berfokus untuk approach maupun berfokus avoidance. Strategi tersebut meliputi: (1) Logical Analysis yaitu usaha kognitif untuk memahami dan menyiapkan secara mental terhadap stresor dan konsekuensi-konsekuensinya; Positive Reappraisal yaitu usaha kognitif untuk menganalisa dan merestrukturisasi masalah dalam sebuah cara yang positif 
sambil terus melakukan penerimaan terhadap realitas situasi; (3) Guidance and Support, yaitu usaha-usaha behavioral untuk mencari informasi, petunjuk dan dukungan; (4) Problem Solving yaitu usaha behavioral untuk bertindak mengatasi masalah secara langsung; (5) Cognitive Avoidance yaitu usaha-usaha kognitif untuk menghindari berpikir tentang masalah; (6) Acceptance-Resignation yaitu usaha kognitif untuk mereaksi masalah dengan cara menerimanya; (7) Alternative Rewards yaitu usaha behavioral untuk melibatkan diri dalam aktivitas pengganti dan menciptakan sumber-sumber kepuasan baru; dan (8) Emotional Discharge yaitu usaha behavioral untuk mengurangi tekanan dengan mengekspresikan perasaan negatif.

Selain strategi koping sebagai prediktor yang bersumber dari internal, peneliti menetapkan prediktor yang bersumber dari eksternal yang akan diuji peranannya yaitu persepsi anak terhadap dukungan sosial, khususnya dukungan dari petugas LPKA. Peneliti menggunakan konsep dukungan petugas yang diusulkan Weiss (dalam Taylor, Peplau \& Sears, 1997) yang menyebut komponen atau dimensi dari bentukbentuk bantuan yang dapat diperoleh dari hubungan dengan orang lain.

Weiss (dalam Taylor, Peplau, \& Sears, 1997) mengemukakan teorinya mengenai fungsi hubungan sosial (Theory of the Provisions of Social Relationship). Weiss mengemukakan adanya 6 (enam) komponen dukungan sosial yang disebut sebagai the social provisions scale, dimana masingmasing komponen dapat berdiri sendiri, namun satu sama lain saling berhubungan. Peneliti menjadikan teori Weiss menjadi teori utama karena teori ini sering dipakai dalam beberapa penelitian tentang dukungan sosial dan mencakup aspek yang luas dari dukungan sosial.

Komponen pertama adalah keterikatan (attachment). Merupakan perasaan akan kedekatan emosional dan rasa aman (ketenangan) dalam diri individu. Sumber dukungan sosial ini yang paling sering dan umum adalah diperoleh dari pasangan hidup atau kekasih yang memiliki hubungan yang harmonis.

Komponen kedua yaitu integrasi sosial (social integration). Merupakan dukungan yang menimbulkan perasaan dalam diri individu bahwa ia termasuk dalam suatu kelompok yang memiliki kesamaan minat dan aktifitas rekreasi. Jenis dukungan ini memungkinkan seseorang untuk memperoleh perasaan memiliki. Jenis dukungan ini seringkali berasal dari teman.

Komponen ketiga yaitu penghargaan/ pengakuan (reassurance of worth). Merupakan pengakuan atas kompetensi, kemampuan, dan keahlian individu. Pada dukungan sosial jenis ini, seseorang akan mendapat pengakuan atas kemampuan dan keahliannya serta mendapat penghargaan dari orang lain. Dukungan ini sering diperoleh dari rekan kerja.

Komponen keempat yaitu hubungan yang dapat diandalkan (reliable alliance). Merupakan keyakinan dalam diri individu bahwa ia dapat mengandalkan orang lain untuk membantunya dalam berbagai kondisi, meliputi kepastian atau jaminan bahwa seseorang dapat mengharapkan keluarga untuk membantu semua keadaan. Dukungan ini sering diperoleh dari anggota keluarga.

Komponen kelima bimbingan (guidance). Dukungan sosial jenis ini adalah adanya hubungan sosial yang dapat memungkinkan seseorang mendapat informasi, saran, atau nasihat yang diperlukan dalam memenuhi kebutuhan dan mengatasi permasalahan yang dihadapi. Dukungan ini sering diperoleh dari guru, mentor, figur orang tua atau figur yang dituakan dalam keluarga.

Komponen keenam kesempatan untuk mengasuh (opportunity for nurturance). Merupakan suatu aspek penting dalam hubungan interpersonal akan perasaan yang dibutuhkan oleh orang lain. Dukungan yang menimbulkan perasaan dalam diri individu bahwa ia bertanggung jawab terhadap kesejahteraan orang lain. Dukungan ini 
sering diperoleh dari anak, cucu, dan pasangan hidup.

Sehubungan dengan penelitian yang akan dilakukan dalam konteks relasi anak didik LPKA dengan petugas, peneliti menetapkan empat komponen dukungan sosial dari enam komponen dukungan sosial Weiss. Empat komponen yang akan dikaji dalam penelitian ini antara lain Keterikatan (Attachment), Penghargaan/ Pengakuan (Reassurance of Worth), Hubungan yang dapat diandalkan (Reliable Alliance) dan Bimbingan (Guidance) yang diberikan petugas sebagai sumber dukungan sosial bagi anak didik LPKA.

Penelitian ini bertujuan untuk mendapatkan data empiris pengaruh strategi koping dan dukungan petugas terhadap kesejahteraan psikologis anak berkonflik dengan hukum, khususnya anak yang menjalani pembinaan di LPKA Tangerang.

\section{Metode Penelitian}

Pendekatan yang digunakan dalam penelitian ini adalah penelitian deskriptif kuantitatif dengan metode korelasional. Populasi penelitian adalah anak didik Lembaga Pembinaan Khusus Anak (LPKA) Tangerang, Banten dengan sampel penelitian berjumlah 43 orang anak berkonflik dengan hukum yang sedang menjalani pembinaan di LPKA Tangerang dan minimal telah menjalani masa pembinaan 6 bulan.

Teknik pengambilan sampel yang dipilih dalam penelitian ini adalah nonprobability sampling dengan teknik purposive sampling. Pengumpul data dalam penelitian ini akan dilakukan dengan menggunakan angket atau kuesioner yang terdiri dari: 1) kuesioner kesejahteraan psikologis integratif (Maslihah, 2017); 2) kuesioner strategi koping,yang terdiri dari delapan jenis strategi koping (Moos, 2002); dan 3) kuesioner dukungan petugas (Maslihah, 2017).

Analisis data yang dilakukan dalam penelitian ini menggunakan program smart
PLS 3.0 untuk menguji validitas dan reliabilitas alat ukur dan menguji model struktural pengaruh strategi koping dan dukungan petugas terhadap kesejahteraan psikologis anak didik LPKA Tangerang.

Adapun reliabilitas dan validitas ketiga alat ukur disajikan pada tabel 1 berikut.

Tabel 1

Validitas dan Reliabilitas Alat Ukur

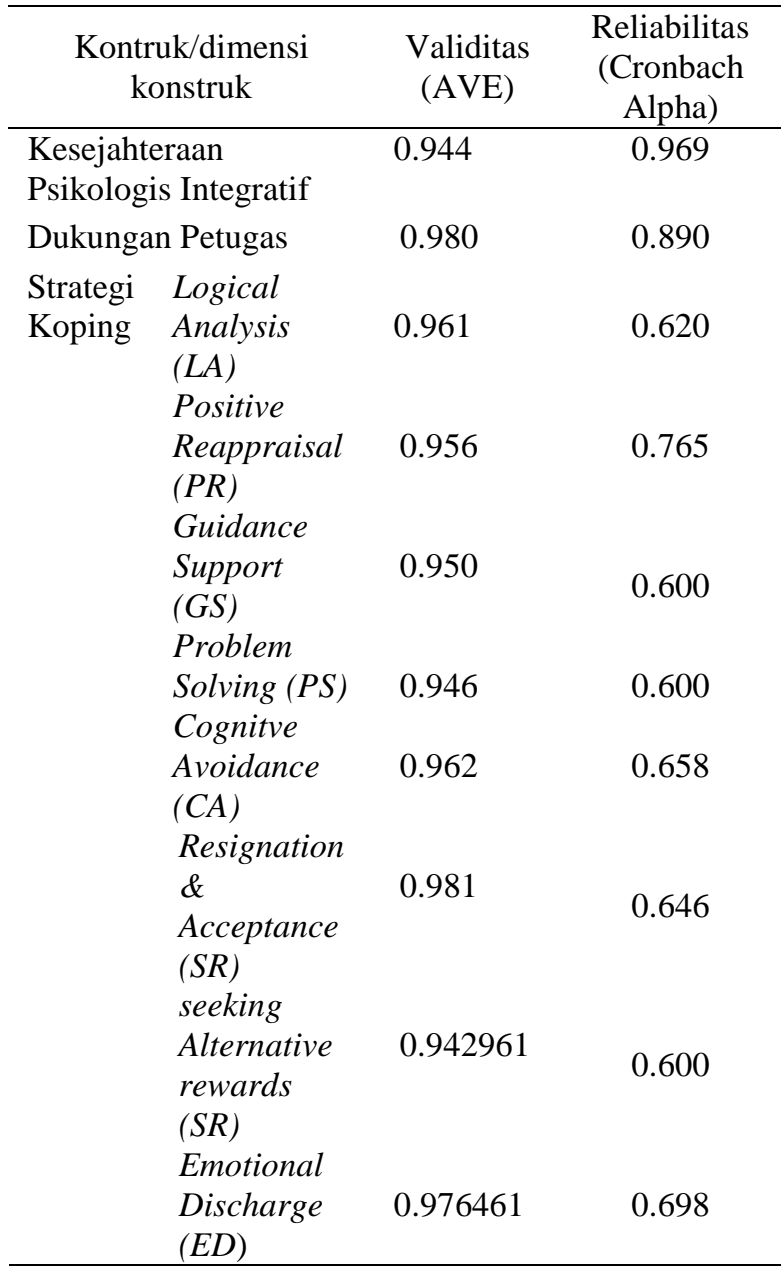

\section{Hasil Penelitian dan Pembahasan}

Berdasarkan data pengujian pada tabel 2, delapan jenis strategi koping: logical analysis, positive reappraisal, guidance support, problem solving, cognitive avoidance, resignation \& acceptance, seeking alternative rewards dan emotional discharge menunjukkan bahwa tidak semua jenis strategi koping memiliki pengaruh yang signifikan terhadap KP anak didik LPKA. Kecuali strategi logical 
Tabel 2

Hasil Uji Pengaruh Strategi Koping (8 Jenis) terhadap Kesejahteraan Psikologis Anak Didik LPKA yang Dimoderasi Dukungan Petugas

\begin{tabular}{|c|c|c|c|c|c|}
\hline & $\begin{array}{c}\text { Original } \\
\text { Sample } \\
(\mathrm{O})\end{array}$ & $\begin{array}{l}\text { Sample } \\
\text { Mean (M) }\end{array}$ & $\begin{array}{l}\text { Standard } \\
\text { Deviation } \\
\text { (STDEV) }\end{array}$ & $\begin{array}{l}\text { T Statistics } \\
(|\mathrm{O} / \mathrm{STERR}|)\end{array}$ & Keterangan \\
\hline Logical Analysis -> KP & -0.045547 & -0.008238 & 0.068441 & 0.665492 & $\begin{array}{c}\text { Tidak } \\
\text { Signifikan }\end{array}$ \\
\hline $\mathrm{DS} \rightarrow \mathrm{KP}$ & 0.261319 & 0.305702 & 0.107682 & 2.426778 & Signifikan \\
\hline Logical Analysis *DS $\rightarrow \mathrm{KP}$ & 0.535368 & 0.462676 & 0.145984 & 3.667300 & Signifikan \\
\hline Positive Reappraisal -> KP & 0.490120 & 0.493428 & 0.079031 & 6.201620 & Signifikan \\
\hline $\mathrm{DS} \rightarrow \mathrm{KP}$ & 0.614577 & 0.628601 & 0.129961 & 4.728933 & Signifikan \\
\hline Positive Reappraisal *DS $\rightarrow$ KP & -0.136515 & -0.152836 & 0.168791 & 0.808779 & $\begin{array}{c}\text { Tidak } \\
\text { Signifikan }\end{array}$ \\
\hline Guidance Support-> KP & -0.070160 & -0.050713 & 0.107784 & 0.650928 & \\
\hline $\mathrm{DS} \rightarrow \mathrm{KP}$ & 0.120336 & 0.136369 & 0.119922 & 1.003447 & $\begin{array}{l}\text { Tidak } \\
\text { Signifikan }\end{array}$ \\
\hline Guidance Support*DS $\rightarrow$ KP & 0.708439 & 0.677555 & 0.186418 & 3.800273 & Signifikan \\
\hline Problem Solving -> KP & 0.414543 & 0.422694 & 0.039958 & 10.374347 & Signifikan \\
\hline $\mathrm{DS} \rightarrow \mathrm{KP}$ & 0.764416 & 0.746363 & 0.065571 & 11.657841 & Signifikan \\
\hline Problem Solving $* \mathrm{DS} \rightarrow \mathrm{KP}$ & -0.271176 & -0.262276 & 0.066932 & 4.051540 & Signifikan \\
\hline Cognitive Avoidance -> KP & 0.218589 & 0.211020 & 0.101026 & 2.163695 & Signifikan \\
\hline $\mathrm{DS} \rightarrow \mathrm{KP}$ & 0.765607 & 0.756135 & 0.102760 & 7.450440 & Signifikan \\
\hline Cognitive Avoidance $* \mathrm{DS} \rightarrow \mathrm{KP}$ & -0.182442 & -0.164830 & 0.173579 & 1.051062 & $\begin{array}{c}\text { Tidak } \\
\text { Signifikan }\end{array}$ \\
\hline resignation \& acceptance -> KP & -0.010404 & -0.015139 & 0.087588 & 0.118785 & \\
\hline $\mathrm{DS} \rightarrow \mathrm{KP}$ & 0.369924 & 0.371951 & 0.076491 & 4.836170 & Signifikan \\
\hline $\begin{array}{l}\text { Resignation \& acceptance *DS } \\
\rightarrow \mathrm{KP}\end{array}$ & 0.418949 & 0.419626 & 0.124272 & 3.371223 & Signifikan \\
\hline $\begin{array}{l}\text { seeking alternative rewards -> } \\
\text { KP }\end{array}$ & 0.942376 & 0.957950 & 0.129935 & 7.252644 & Signifikan \\
\hline $\mathrm{DS} \rightarrow \mathrm{KP}$ & 0.983354 & 1.102412 & 0.119669 & 9.052946 & Signifikan \\
\hline $\begin{array}{l}\text { seeking alternative rewards *DS } \\
\rightarrow \mathrm{KP}\end{array}$ & -0.984219 & -1.014858 & 0.210226 & 4.681730 & Signifikan \\
\hline emotional discharge --> KP & 0.482859 & 0.472582 & 0.091848 & 5.257145 & Signifikan \\
\hline $\mathrm{DS} \rightarrow \mathrm{KP}$ & 1.099410 & 1.094307 & 0.068721 & 15.998149 & Signifikan \\
\hline emotional discharge $* \mathrm{DS} \rightarrow \mathrm{KP}$ & -0.554642 & -0.552092 & 0.101433 & 5.468052 & Signifikan \\
\hline
\end{tabular}

Keterangan:

KP : Kesejahteraan Psikologis Anak Didik LPKA (KP)

DS : Dukungan Petugas

analysis, guidance support, resignation \& acceptance, semua jenis strategi koping berpengaruh terhadap KP anak berkonflik dengan hukum atau anak didik LPKA. Sementara dukungan petugas memiliki pengaruh langsung dan signifikan terhadap KP anak, pada semua model struktural atau dalam model strategi koping, kecuali pada guidance support.

Paparan di atas menunjukkan bahwa KP anak didik LPKA pada dasarnya bisa dipengaruhi oleh faktor dari dalam diri anak, yaitu strategi koping dan faktor luar diri anak, yaitu petugas LPKA. Namun 
demikian dukungan petugas tidak selalu mampu memberi pengaruh signifikan terhadap KP anak didik LPKA pada saat keduanya, (strategi koping dan dukungan petugas) dilakukan secara pada saat bersamaan.

Terkait dengan kesejahteraan psikologis anak berkonflik dengan hukum, hasil penelitian ini menunjukkan bahwa dari delapan strategi koping anak didik LPKA menunjukkan bahwa strategi possitive reapraisal, problem solving, cognitive avoidance, seeking alternative rewards dan emotional discharge berpengaruh langsung terhadap pembentukan kesejahteraan psikologis anak. Hal ini menunjukkan bahwa anak berkonflik dengan hukum yang menjalani pembinaan di LPKA memiliki kemampuan mengatasi masalah atau koping untuk memunculkan kesejahteraan psikologisnya.

Dukungan petugas sebagai faktor eksternal berpengaruh langsung terhadap kesejahteraan psikologis berkonflik dengan hukum. Hanya saja dukungan petugas tidak selalu bisa berperan sebagai variabel moderator saat anak terjadi relasi strategi koping possitive reappraisal dan cognitive avoidance. Sementara pada saat anak menggunakan enam strategi koping lain, dukungan petugas mampu menjadi variabel moderator dalam hubungan strategi koping dan kesejahteraan psikologis anak. Dengan kata lain anak didik LPKA juga menggabungkan strategi koping yang dimilikinya dengan peran serta atau dukungan petugas untuk membentuk kesejahteraan psikologis .

Paparan di atas menunjukkan bahwa anak berkonflik dengan hukum merupakan kelompok anak yang berada pada usia remaja, pada dasarnya memiliki keterampilan dalam mengatasi kesulitan. Untuk menjaga kondisi psikologis saat menghadapi situasi menekan, anak yang menjalani pembinaan diLPKA memiliki sumber daya internal, yaitu kemampuan menggunakan beberapa jenis strategi koping. Meskipun demikian, kehadiran petugas LPKA sebagai figur yang dapat membantu diri anak dalam mengatasi kesulitan masih diperlukan. Anak-anak ini masih membutuhkan bimbingan dan pendampingan orang dewasa, dalam hal ini anak didik LPKA membutuhkan peran petugas sebagai figur pengganti orang tua khususnya dalam pembentukan kesejahteraan psikologis. Petugas LPKA merupakan sumber dukungan sosial bagi anak didik LPKA. Pada lingkungan di luar LPKA, sumber dukungan ini seringkali diperoleh dari anggota keluarga. Temuan penelitian ini mendukung penelitianpenelitian terdahulu terkait pentingnya peranan dukungan petugas bagi anak-anak yang sedang menjalani pembinaan di lembaga sejenis LPKA (Edwards; 2008); Solichatun, 2012; Laan dan Eichelsheim 2013; Maslihah dkk., 2016).

\section{Profile Dukungan Petugas}

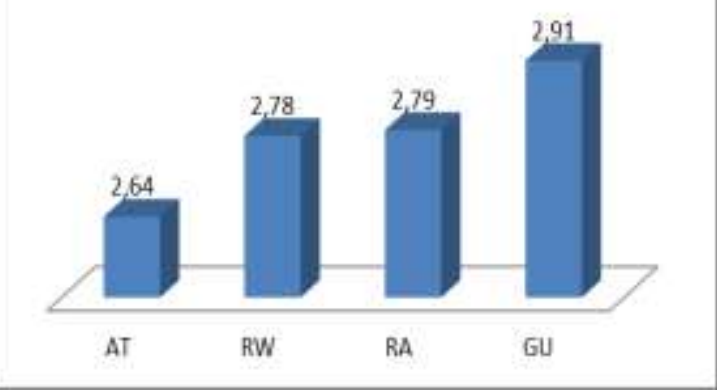

Gambar 1. Gambaran Rata-Rata Nilai Komponen Dukungan Petugas

Keterangan:

AT: kedekatan emosi (attachment),

RW: pengakuan dan penghargaan (reassurance of worth),

RA: bantuan yang dapat diandalkan (reliable alliance)

GU: arahan dan bimbingan (guidance)

Diagram 1 di atas menunjukkan bahwa dukungan petugas yang dipersepsikan bagi anak didik LPKA paling besar didapat melalui dimensi bimbingan dan arahan (guidance). Artinya saat menjalani pembinaan di LPKA, anak membutuhkan kehadiran petugas yang dapat memberinya 
bimbingan, informasi dan arahan terutama saat anak mendapatkan masalah atau kesulitan. Hal ini menegaskan bahwa anak didik LPKA pada dasarnya merupakan kelompok anak yang belum bisa sepenuhnya lepas dari orang tua/keluarga dan secara psikologis, anak-anak ini belum mandiri. Anak didik LPKA membutuhkan kehadiran orang tuanya, keluarga, namun pada kenyataannya mereka harus hidup terpisah dari orang tua dan karena kondisi itu petugas LPKA dipersepsi anak mampu mengganti figur pengganti orang tua.

Dalam kaitannya dengan kesejahteraan psikologis anak didik LPKA, hasil penelitian ini menunjukkan bahwa dukungan petugas sendiri memberikan pengaruh yang signifikan terhadap kesejahteraan psikologis anak didik LPKA. Hal ini menunjukkan semakin tinggi dukungan petugas, maka kesejahteraan psikologis (KP) anak berkonflik dengan hukum akan semakin meningkat. Hal ini sejalan dengan pendapat Ullah dan Warr (dalam Oxford, 1992) bahwa dukungan sosial dapat meningkatkan kesehatan fisik dan psikologis individu dengan adanya ataupun tanpa tekanan. Khusus kondisi LPKA, saat anak menjalani pembinaan di LPKA, kehadiran petugas dapat mengurangi tekanan yang dirasakan anak sehingga anak diharapkan dapat mengikuti proses pembinaan dengan baik. Sebagaimana diungkapkan Oxford (1992) bahwa dukungan sosial bekerja dengan tujuan untuk memperkecil pengaruh dari tekanan-tekanan atau stres yang dialami individu. Dengan kata lain dukungan petugas pada anak didik LPKA dapat berfungsi sebagai buffer effect yang dapat mengurangi tekanan-tekanan sehubungan kondisi yang terjadi di lingkungan LPKA.

\section{Simpulan dan Saran}

Kesejahteraan psikologis anak berkonflik dengan hukum yang menjalani pembinaan di LPKA dapat dipengaruhi oleh faktor internal diri anak, yaitu strategi koping dan bisa dipengaruhi oleh faktor eksternal, yaitu adanya dukungan petugas.
Anak berkonflik dengan hukum memiliki kemampuan melakukan beberapa jenis strategi koping untuk tercapainya kesejahteraan psikologis integratif. Demikian juga dukungan petugas LPKA berpengaruh langsung terhadap kesejahteraan psikologis anak berkonflik dengan hukum atau anak didik LPKA. Hanya saja dukungan petugas dapat berperan sebagai variabel moderator dalam hubungan strategi koping dan kesejahteraan psikologis integratif, kecuali pada strategi koping possitive reappraisal dan cognitive avoidance. Dengan demikian, secara umum anak cukup mampu menggabungkan dukungan yang diberikan petugas dengan kemampuan koping yang dimiliknya untuk mencapai kesejahteraan psikologis kecuali saat ia menggunakan strategi possitive reappraisal dan cognitive avoidance.

Penelitian ini akan lebih banyak memberikan informasi apabila dikaji perbedaan kondisi anak berdasarkan perbedaan kasus yang dilakukan berkonflik dengan hukum. Disertai dengan menyertakan data kualitatif maka diharapkan dapat diperoleh dinamika proses psikologis pada anak berkonflik dengan hukum khususnya dikaitkan dengan pembentukan kesejahteraan psikologis.

Selain itu mengingat keterlibatan orang tua dalam proses perkembangan anak memiliki peranan penting, maka diperlukan data tambahan terutama data kualitatif terkait kondisi orang tua dan keterlibatan orang tua dalam proses perkembangan anak berkonflik degan hukum khususnya saat anak menjalani proses pembinaan di LPKA.

Temuan penelitian ini diharapkan bermanfaat bagi penyusunan kebijakan terkait pembinaan anak berkonflik hukum yang menjalani pembinaan di LPKA. Lebih lanjut terkait temuan urgensi peran petugas bagi pembentukan kesejahteraan psikologis anak didik LPKA, khususnya bagi Kementerian Hukum dan Hak Asasi Manusia diharapkan bisa menjadi masukan 
dalam penyusunan program peningkatan kapasitas dan keterampilan petugas LPKA.

\section{Daftar Pustaka}

Barnet, E. S., Perry, R., Azzi, V. F., Shetgiri, R., Ryan, G., Dudovitz, R., Zima B., \& Chung P. J. (2015). Incarcerated youths' perspectives on protective factors and risk factors for juvenile offending: A qualitative analysis. American Journal of Public Health, 105(7).

Bradshaw, J., Hoelscher, P., \& Richardson, D. (2006) Social Policy Research Unit (SPRU): An index of childwell being in the European Union', social indicators research. New York: Springer.

Cesaroni, C., \& Peterson-Badali, M. (2010). Understanding the adjustment of incarcerated young offenders: A Canadian example. Youth Justice, 10(2), 107125.

Diener, E. (1984). Subjective well-being. Psychological Bulletin, 95, 542-575.

Diener, E. (2009). Scale of positive and negative experience. Diakses pada 2 Juli, 2012, dari http://www.positivepsychology.com

Edwards, W. T. (2008). How do variation in social supports resources of prisoners correlate with psychological distress? (Disertasi). University of Kentucky, Lexington, Kentucky.

Faizza, R. N. (2009). Pengaruh dukungan sosial terhadap resilien narapidana remaja di lembaga pemasyarakatan anak Blitar (Skripsi tidak diterbitkan). Fakultas Psikologi Universitas Islam Maulana Malik Ibrahim, Malang.

Handayani, T. P. (2012). Kesejahteraan psikologis narapidana remaja di lembaga pemasyarakatan anak Kutoardjo: Studi kualitatif fenomenologis (Skripsi tidak diterbitkan).

Universitas

Diponegoro.

Helsen, M., Vollebergh, W., \& Meeus, W. (2000). Social support from parents and friends and emotional problems in adolescence. Journal of Youth and Adolescence, 29, 319-335.

Laan, A. V., \& Eichelsheim, V. (2013). Juvenile adaptation to imprisonment: Feelings of safety, autonomy and well-being, and behaviour in prison. European Journal of Criminology, 4, 424-443.

Maitland, A. S., \& Sluder, R. D. (1996). Victimisation in prison: A study of factors related to the general wellbeing of youthful inmates. Federal Probation, 60(2), 24-31.

Maslihah, S., Siregar, J. R., Koesma, R. E., M, \& Agustiani, H. (2015). Analisis kesejahteraan subyektif anak didik lembaga pemasyarakatan anak. Prosiding Konferensi Nasional Community Well-Being. Bandung: Fakultas Psikologi Universitas Maranatha.

Maslihah, S., Siregar, J. R., Koesma, R. E., M, \& Agustiani, H. (2016).Coping strategies children in the guidance institutional for children. Prosiding International Conference on Economics, Business and Social Science. Malang: Universitas Islam Negeri Malang.

Maslihah, S. (2017). Pengembangan alat ukur kesejahteraan psikologis integratif dan dukungan petugas (Makalah tidak diterbitkan). Program Doktor Psikologi Universitas Padjadjaran.

Mohino, S., Kirchner, T., \& Forns, M. (2004). Coping strategies in young male prisoners. Journal of Youth and Adolescence, 33, 41-49.

Moos, R. H. (2002). The mystery of human context and coping: An unraveling of clues. American Journal of Community Psychology, 30(1), 6788. 
Ochse, R., \& Plug, C. (1986). Crosscultural investigation of the validity of Erickson's theory of personality development. Journal of Personality and Social Psychology, 50, 12401250.

Oxford, J. (1992). Community psychology: Theory \& practice. London: John Wiley and Sons.

Puspita, H. N. (2013). Pengaruh self-esteem dan perceived social support terhadap psychological well-being anak didik lapas anak pria Tangerang (Skripsi tidak diterbitkan). Universitas Islam Negeri Syarif Hidayatullah, Jakarta.
Solichatun, Y. (2012). Regulasi emosi dan dukungan sosial sebagai moderator hubungan stres dan resiliensi pada anak didik di lembaga pemasyarakatan anak (Disertasi tidak diterbitkan). Universitas Gajah Mada, Yogyakarta.

Taylor, S. E., Peplau, L. A., \& Sears, J. O. (1997). Social psychology. New Jersey: Prentice Hall.

Weiss, H. B., \& Lopez, M. E. (1999). New strategies in foundation grantmaking for children and youth. Cambridge, MA: Harvard Family Research Project.

Whitehead, D. L., \& Steptoe, A. (2007). Prison. Dalam G. Fink, Encyclopedia of Stress (ed. 2), 3, 217-221. 